\title{
PENGARUH MEDIA SOSIAL TERHADAP HASIL BELAJAR DASAR PENGUKURAN LISTRIK (Studi Pada SMKN 34 Jakarta)
}

\author{
${ }^{1}$ Inggih Piany Syanita, ${ }^{2}$ Faried Wadjdi, ${ }^{3}$ Aris Sunawar. \\ 1,2,3 Pendidikan Teknik Elektro, Fakultas Teknik, Universitas Negeri Jakarta. \\ ${ }^{1}$ E-mail : pianyinggih@gmail.com
}

\begin{abstract}
The aim of this study is to find influence social media against the results of learning measurement electricity at 34 vocational school.

Populations of this study is student in class X at major electrical engineering. Samples taken by 30 students form a different class. The method used is experimental method and used test instrument multiple choice and questionnaire.

To test the hypothesis in this research used analysis regression linier sederhana with uji-F. Before analysis regression linier sederhana with uji-F the firs must tes rules that is normality, homogeneity, $t$-tes and linierity. The results of analysis regression linier with standard significant $0,05 F_{\text {value }}>F_{\text {table }}=10,93>4,20$ and the value of determinasi $=28,09$ then 28,09\% from variable the result of learning student influenced form used social media and if not using social media.
\end{abstract}

Keywords: The Result Of Learning, Social Media.

\begin{abstract}
Abstrak
Tujuan penelitian ini adalah untuk mengetahui pengaruh media sosial terhadap hasil belajar dasar pengukuran listrik (studi pada SMKN 34 Jakarta).

Populasi penelitian ini adalah siswa kelas X jurusan teknik instalasi listrik SMKN 34 Jakarta. Sampel yang diambil sebanyak 30 siswa dari 2 kelas yang berbeda dengan menggunakan metode quasy experimental dan instrument penelitian ini menggunakan tes pilihan ganda dan kuesioner.

Untuk menguji hipotesis dalam penelitian ini digunakan analisis regresi linier sederhana dengan uji-F. Sebelumnya dilakukan uji persyaratan terlebih dahulu, yaitu uji normalitas, homogenitas, uji-t dan linieritas. Didapatkan analisis regresi linier sebesar dengan taraf signifikansi 0,05 $\mathrm{F}_{\text {hitung }}>\mathrm{F}_{\text {tabel }}$ yaitu 10,93 $>4,20$ dan nilai koefisien determinasi sebesar 28,09 yang berarti 28,09 persen dari variabel hasil belajar dipengaruhi oleh penggunaan media sosial dan tidak dari media sosial.
\end{abstract}

Kata Kunci: Hasil Belajar, Media Sosial.

\section{PENDAHULUAN}

Saat ini diperlukan pendidikan yang dapat menghasilkan sumber daya manusia yang berkemauan untuk senantiasa meningkatkan kualitasnya secara terus menerus dan berkesinambungan. Suatu program pembelajaran dapat mencapai hasil seperti yang diharapkan apabila direncanakan dengan baik. Terdapat tiga hal yang menjadi perhatian banyak pihak dalam kegiatan pembelajaran. Materi apa yang diajarkan, bagaimana cara mengajarkan, serta cara mengetahui bahwa proses pembelajaran dapat berlangsung dengan efektif. Proses kegiatan pembelajaran dapat dilakukan dengan memanfaatkan teknologi yang berkembang saat ini. Beragam teknologi yang berkembang saat ini yang dapat dijadikan sebagai bahan dalam proses pembelajaran salah satunya adalah teknologi komunikasi.

Perkembangan teknologi sudah seharusnya diimbangi dengan peningkatan kualitas pendidikan. Namun kualitas pendidikan yang ada kini kurang mendapatkan perhatian yang berarti. Berdasarkan penelitian yang didapat saat penulis PKM di SMKN 34 Jakarta, siswa tidak sepenuhnya melibatkan teknologi yang mereka miliki untuk media pembelajaran, sebagai contoh teknologi komunikasi handphone yang sebagian besar siswa gunakan hanya untuk kegiatan komunikasi ,bermain game, mendengarkan musik dll. Siswa sering jenuh bila hanya mendengarkan guru menjelaskan materi. Pada awal pembelajaran siswa sering merasa kebingungan disaat guru mulai menjelaskan, dikarenakan siswa tidak mengetahui materi yang akan di ajarkan terlebih dahulu yang mengakibatkan siswa tidak memiliki pengetahuan awal sebelum pembelajaran dan 
setelah selesai pembelajaran siswa tidak dapat mempelajari kembali materi yang telah diajarkan guru saat dirumah atau dimanapun karena tidak memiliki nya sumber belajar dan pembelajaran di sekolah masih menggunakan metode ceramah dan power point yang tidak dapat dibawa pulang siswa untuk mempelajari ulang materi dirumah, sementara kehidupan di luar sekolah memfasilitasi mereka untuk mengakses berbagai teknologi canggih yang menghibur dan menarik yang dapat dijadikan alat pembelajaran secara mandiri melalui handphone dan mengubah cara penggunaan handphone menjadi hal yang positif untuk membaca materi pelajaran.

Dasar pengkuran listrik merupakan pelajaran produktif yang terdapat di jurusan teknik pemanfaatan tenaga listrik di SMKN 34. Terdapat teori dan praktikum di dalam pelajaran dasar pengukuran listrik. Teori di dalam dasar pengukuran listrik mengacu pada perhitungan listrik yang didalamnya banyak rumus - rumus untuk menentukan jawabannya serta konsep ilmu kelistrikan yang harus dipahami. Telah diketahui bahwa dasar pengukuran listrik merupakan pelajaran yang sulit dipahami siswa terlebih pada materi - materi teori perhitungan listrik. Sulit nya pelajaran dasar pengukuran listrik mengakibatkan rendahnya nilai pelajaran dasar pengukuran siswa. Menurut hasil nilai ulangan dasar pengukuran listrik bahwa 99\% siswa mendapatkan nilai kurang dari KKM (Kreteria Ketuntasan Minimal). Dengan hasil range nilai siswa rata-rata 38-60 yang didapatkan siswa.

Mobile learningadalah salah satu alternatif bahwa layanan pembelajaran harus dilaksanakan di mana pun dan kapan pun. Mobile Learningatau sering disebut dengan m-learning memang masih dalam tahap pengembangan terlebih dengan banyaknya perkembangan perangkat dan operasi sistem yang beragam, membuat perkembangan $\mathrm{m}$ learning semakin lebih terbuka. Diantara bebarapa aplikasi yang tersedia didalam OS Android penulis memilih aplikasi Instagram, Path dan Twitteruntuk dijadikan media pembelajaran sebab ketiga aplikasi tersebut dapat mengarahkan siswa melakukan suatu kegiatan (kerja). Penulis membuat akun ketiga media sosial tersebut dengan nama (user name) MLEARNINGDPL. Siswa dapat mengetahui konsep dan rumus didalam mata pelajaran dasar pengukuran listrik berdasarkan penjelasan gambar sehingga dapat membantu dalam proses belajar awal secara mandiri dengan memanfaatkan teknologi handphone sebagai media pembelajaran untuk meningkatkan hasil belajar dasar pengukuran listrik yang dapat dilakukan dimana saja dan kapan saja setelah materi telah di upload.

\section{METODE}

\section{Tempat, Waktu, Subjek Penelitian}

Dilaksanakan di SMKN 34 Jakarta, pada bulan Mei-Juni 2016 dengan subjek penelitian adalah siswa kelas X jurusan Teknik Instalasi Listrik

\section{Populasi dan Sampel}

Tabel 1. Data populasi sampel

\begin{tabular}{lll}
\hline Kelompok & Kelas & $\begin{array}{l}\text { Jumlah } \\
\text { Sampel }\end{array}$ \\
\hline Kelas Kontrol & X L-1 & 30 orang \\
Kelas & X L-2 & 30 orang \\
Eksperimen & & \\
& Jumlah & 60 orang \\
\hline
\end{tabular}

\section{Metode dan Rancangan Penelitian}

Penelitian kuantitatif, berupa metode quasy eksperimental. Desain penelitian

Tabel 2. Metode Penelitian

\begin{tabular}{lll}
\hline Kelompok & Perlakuan & Hasil \\
\hline Eksperimen (E) & $\mathrm{X}_{1}$ & $\mathrm{O}^{1}$ \\
Kontrol (K) & $\mathrm{X}_{2}$ & $\mathrm{O}^{2}$ \\
\hline
\end{tabular}

\section{Instrumen}

Instrumen Tes dan Instrumen Non Tes. Instrumen tes berupa soal hasil belajar sebanyak 40 soal dan instrumen non tes berupa soal kuesioner media sosial sebanyak 45 soal. Soal instrumen akan di validasi dan relibilitas soal.

\section{Teknik Pengumpulan Data}

Teknik pengumpulan data dengan metode dokumentasi, pengumpulan data tes, kuesioner.

\section{Teknik Analasis Data}

A. Uji Persyaratan Analisis menggunakan uji normalitas dan homogenitas.

B. Pengujian Hipotesis menggunakan uji t, uji linieritas, uji hipotesis regresi sederhana. 


\section{HASIL DAN PEMBAHASAN}

Hasil Belajar Dasar Pengukuran Listrik yang Menggunakan Media Sosial

Sampel ini ialah siswa yang menggunakan media sosial adalah 30 siswa. Nilai minimal $=70$, nilai maksimal $=97,5$, nilai rata-rata $=82$, simpangan baku $=6,58$, median $=81,5$ dan modus $=80,57$. Dari data tersebut dengan menggunakan statistika untuk mendapatkan kelas interval diperoleh 5 merupakan interval yang dapat digunakan untuk membuat daftar distribusi.

\section{Hasil Belajar Dasar Pengukuran Listrik yang Tidak Menggunakan Media Sosial}

Sampel ini ialah siswa yang menggunakan media sosial adalah 30 siswa. Nilai minimal $=60$, nilai maksimal $=82,5$, nilai rata-rata $=77,9$, simpangan baku $=5,98$, median $=77,94$ dan modus $=78,83$. Dari data tersebut dengan menggunakan statistika untuk mendapatkan kelas interval diperoleh 4 merupakan interval yang dapat digunakan untuk membuat daftar distribusi data.

\section{Hasil Kuesioner Media Sosial}

Sampel ini ialah siswa yang menggunakan media sosial adalah 30 siswa. Terdapat tiga media sosial didalam kuesioner yang di jawab siswa, yakni media sosial Instagram, Path dan Twitter. Media sosial Instagram memiliki jumlah skor nilai 1236 dengan nilai terbesar $=60$ dan nilai terkecil $=15$. Media sosial Path memiliki jumlah skor 1412 dengan nilai terbesar $=60$ dan nilai terkecil $=25$. Media sosial Twitter memiliki jumlah skor 434 dengan nilai terbesar $=20$ dan nilai terkecil $=$ 5.

\section{Hasil Pengujian Normalitas}

Perhitungan dilakukan dengan menggunakan uji lilifors dengan taraf signifikasi $\alpha=0,05$. Hasil perhitungan diperoleh dari sampel siswa Mata Pelajaran Dasar Pengukuran Listrik yang menggunakan media sosial diperoleh nilai $\mathrm{L}_{\text {hitung }}=0,130$, sedangkan $\mathrm{L}_{\text {tabel }(0,05)}=0,161$. Jadi $\mathrm{L}_{\text {hitung }}<\mathrm{L}_{\text {tabel}}$, maka Ho diterima. Dengan demikian dapat disimpulkan bahwa siswa yang menggunakan media sosial berdistribusi normal.
Untuk sampel siswa yang tidak menggunakan media sosial diperoleh hasil perhitungan Hasil perhitungan diperoleh dari sampel siswa Mata Pelajaran Dasar Pengukuran Listrik yang tidak menggunakan media sosial diperoleh nilai $\mathrm{L}_{\text {hitung }}=0,119$, sedangkan $\mathrm{L}_{\text {tabel }(0,05)}=0,161$. Jadi $\mathrm{L}_{\text {hitung }}<\mathrm{L}_{\text {tabel}}$, maka Ho diterima Dengan demikian dapat disimpulkan data siswa yang menggunakan media sosial berdistribusi normal.

\section{Hasil Pengujian Homogenitas}

Pengujian homogenitas sampel yang dilakukan terhadap siswa yang menggunakan media sosial dengan yang tidak menggunakan media sosial dilakukan menggunakan uji $\mathrm{F}$ dengan taraf signifikan 0,05 maka hasil perhitungan menunjukan $F_{\text {hitung }}<F_{\text {tabel }}$ atau 1,54 $<1,94$. Artinya dari perhitungan ini dapat disimpulkan populasi $\mathrm{X}_{\mathrm{A}}$ dan $\mathrm{X}_{\mathrm{B}}$ berasal dari variansi yang homogen.

\section{Hasil Uji t}

Dari perhitungan, untuk perhitungan uji $t$ diperoleh nilai $t_{\text {hitung }}=2,331$ sedangkan $t_{\text {tabel }}=$ 2,002, untuk derajat kebebasan 58. Berdasarkan kreteria pengujian yang digunakan karena $t_{\text {hitung }}>$ $\mathrm{t}_{\text {tabel }}$, maka Ho ditolak dan Hi diterima. Sehingga dapat disimpulkan terdapat perbedaan hasil belajar mata pelajaran dasar pengukuran listrik yang menggunakan media sosial dengan yang tidak menggunakan media sosial.

\section{Hasil Pengujian Linieritas}

Pengujian linieritas dilakukan terhadap media sosial dan hasil belajar. Dengan taraf signifikan 0,05 maka hasil perhitungan menunjukan $F_{\text {hitung }}<$ $F_{\text {tabel }}$ atau $0,63<2,41$. Artinya dari perhitungan ini dapat disimpulkan variabel media sosial dan variabel hasil belajar memiliki hubungan yang linier.

\section{Hasil Pengujian Hipotesis Penelitian}

$F_{\text {hitung }}>F_{\text {tabel }}$ yaitu $10,93>4,20$ maka Ho ditolak yang berarti bahwa ada pengaruh yang signifikan antara penggunaan media sosial terhadap hasil belajar dasar pengukuran listrik siswa SMK Negeri 34 Jakarta. 
Setelah dihitung besar determinasi didapatkan nilai koefisien determinasinya yaitu sebesar 28,09\% Jika dibandingkan dengan interpretasi koefisien determinasi maka tergambar pengaruh penggunaan media sosial adalah pengaruh cukup berarti.

\section{KESIMPULAN DAN SARAN Kesimpulan}

1. Terdapat perbedaan hasil belajar dasar pengukuran listrik yang menggunakan media sosial dengan yang tidak menggunakan media sosial. Terbukti dari hasil distribusi data dan frekuensi, pada siswa yang menggunakan media sosial memiliki nilai rata-rata 82 dan pada siswa yang tidak menggunakan media sosial memperoleh nilai rata-rata sebesar 77,9.

2. Berdasarkan hasi pengujian menggunakan uji$\mathrm{t}$, diperoleh hasil $t_{\text {hitung }}=2,331$ sedangkan $t_{\text {tabel }}$ $=2,002$ untuk derajat kebebasan 58 . Berdasarkan kreteria pengujian yang digunakan karena $t_{\text {hitung }}>t_{\text {tabel }}$, maka Ho ditolak dan Hi diterima. Sehingga dapat disimpulkan terdapat perbedaan hasil belajar mata pelajaran dasar pengukuran listrik yang menggunakan media sosial dengan yang tidak menggunakan media sosial.

3. Pengujian linieritas dilakukan terhadap media sosial dan hasil belajar. Dengan taraf signifikan 0,05 maka hasil perhitungan menunjukan $F_{\text {hitung }}<F_{\text {tabel }}$ atau $0,63<2,41$. Artinya dari perhitungan ini dapat disimpulkan media sosial dan hasil belajar memiliki hubungan positif yang linier.

4. Berdasarkan uji regresi sederhana menunjukan bahwa $F_{\text {hitung }}>F_{\text {tabel }}$ yaitu 10,93 $>$ 4,20 maka Ho ditolak yang berarti bahwa ada pengaruh yang signifikan antara penggunaan media sosial terhadap hasil belajar dasar pengukuran listrik siswa SMK Negeri 34 Jakarta.

\section{Saran}

Berdasarkan hasil penelitin yang telah dicapai, maka disarankan agar dalam proses belajar guru dapat menerapkan media sosial sebagai media pembelajaran, dimana di dalam penggunaan media sosial siswa lebih paham dan mendapatkan wawasan secara praktis, mudah dengan hanya menggunakna satu buah handphone dan dapat dilakukan dimana saja dan kapan saja siswa dapat belajar materi dasar pengukuran listrik. Guru dapat mengaplikasikan penggunaan media sosial yang dijadikan media pembelajaran ke semua matapelajaran yang ada di sekolah.

\section{DAFTAR PUSTAKA}

Arikunto, S. (2013). Prosedur Penelitian. Jakarta: Rineka Cipta.

Darmawan, D. (2012). Teknologi Pembelajaran. Bandung: Rosda.

Dimyati. (2006). Belajar dan Pembelajaran. Jakarta: PT Rineka Cipta.

Dixon, J. (2012). Social Media For School Leaders. San Franscisco: Jossey-Bass.

Hamalik, O. (2009). Proses Belajar Mengajar. Jakarta: PT Bumi Aksara.

Kaplan, M. A., \& dkk. (2010). Users Of The World, Unite! The Challenges and Oppertunities Of Social Media. Busniess Horizons.

Kristianto, A. (2001). Connect! Panduang Lengkap Browsing.Jakarta: Super Computer Publishing.

Sharief, S. (2014). Buku Pintar Gadget Android. Jakarta: Niaga Swadaya.

Soedijarto. (1993). Menuju Pendidikan Nasional yang Relevan dan Bermutu. Jakarta: Balai Pustaka.

Sudjana, N. (2001). Penilaian Hasil Proses Belajar Mengajar. Bandung: Remaja Rosdakarya.

Sugiyono. (2013). Metode Penelitian Kuantitatif Kualitatif dan $R \& D$. Bandung: Alfabeta 